\title{
Flash Preparation of Carbenoids: A Different Performance of Cyanogen Bromide
}

\author{
MOHAMMAD JALILZADEH HEDAYAT ${ }^{1 *}$ and NADER NOROOZI PESYAN² \\ 'Department of Chemistry, Faculty of Science, Ahar Branch, Islamic Azad University, Ahar, Iran. \\ ${ }^{2}$ Department of Chemistry, Faculty of Science, Urmia University, Urmia, Iran. \\ ${ }^{*}$ Corresponding author E-mail: m-jalilzadeh@iau-ahar.ac.ir \\ http://dx.doi.org/10.13005/ojc/300477
}

(Received: August 01, 2014; Accepted: September 01, 2014)

\begin{abstract}
Cyanogen halides are known substances for the cyanating reaction. There are a few evidences for bromination reaction too. On the other hand carbenes are known as very important substances due to their remarkable reactions. Unfortunately carbenes at room temperature are very unstable and there is not a simple method for preparation of them. In most cases the isolation is not possible. We have reported a new reliable and fast preparation method of almost stable carbenoids. The mechanism of the formation has been discussed.
\end{abstract}

Key words: Carbene, Carbenoid, Cyanogen halides, Active carbons.

\section{INTRODUCTION}

Cyanogen halides are known as important synthetic substances since they are strong cyanating agents. For instance cyanogen iodide reacts with the tertiary amine ring of marcfortine $A$ to give cyano and iodocyano substituted products ${ }^{1}$. Also cyanogen iodide has been used as a reagent for disulfide bond formation in peptides ${ }^{2}$.

Cyanogen bromide is a very useful and extensively used reagent for the synthesis of cyanamides ${ }^{3}$. It is a colorless or white crystalline solid that decomposes in the presence of moisture and has a very small liquid range $\left(\mathrm{mp} 50-53^{\circ} \mathrm{C}\right.$, bp $61-62{ }^{\circ} \mathrm{C}$ ). It is cheap and can be synthesized by the reaction of sodium cyanide with bromine in aqueous medium ${ }^{4}$. CNBr produces electrophilic cyanide. Therefore, it is attacked by nucleophiles such as amines, alcohols and thiols.

Primary and secondary amines react with $\mathrm{CNBr}$ to give mono- and dialkylcyanamides ${ }^{5,6,7}$. $\mathrm{CNBr}$ is a very useful reagent for the preparation of aryl nitriles. It condenses with toluene in the presence of $\mathrm{AlCl} 3$ to give p-toluonitrile ${ }^{8}$. $\mathrm{CNBr}$ is known to convert carboxylic acids to nitriles at 
higher temperature under sealed-tube conditions. The reaction involves the intermediacy of a carboxylic cyanic anhydride. In anhydrous benzene, the carboxylic cyanic anhydride may be trapped and, in the presence of pyridine, symmetrical anhydrides may be produced in yields of $78-95 \%$. Von Braun found that a dialkyl thioether is cleaved by $\mathrm{CNBr}$, at a somewhat elevated temperature (60$70{ }^{\circ} \mathrm{C}$, sealed tube), to an alkyl thiocyanate and an alkyl bromide ${ }^{10}$. More recently, this reaction has been used for the selective cleavage of methionine peptides ${ }^{11}$ and other peptides ${ }^{12}$. Reaction between cyanogen bromide and some 3-amino-1,1diphenylpropanes, variously substituted at C-1, leads either to $\mathrm{N}$-cyano derivatives or to tetrahydrofurans ${ }^{13}$. Cyanogen bromide is a capable reagent for the synthesis of cyanamides ${ }^{3}$, cyanates ${ }^{14}$, and also used to selective cleavage of the methionyl peptide bonds in ribonuclease ${ }^{15}$ and etc. Nonetheless this compound also is useful to simultaneity brominating and cyanating; the bromination and cyanation of imidazoles ${ }^{16}$, free radical reaction with alkanes that result in bromination of alkanes ${ }^{17}$ and $\alpha$-bromination of $\beta$ aminoenones ${ }^{18}$. By the way the Von Braun reaction is an organic reaction in which a tertiary amine reacts with cyanogen bromide to an organocyanamide ${ }^{19}$. The reaction of tertiary amines with $\mathrm{CNBr}$ yield disubstituted cyanamides and an alkyl bromide ${ }^{20}$. The bromodealkylation reaction has also been used to cleave the ring system of aziridine compounds ${ }^{21}$. Routine reactions of Cyanogen bromide have been presented in scheme 1. Although cyanogen bromide is a well known reagent, it has never been used as a carbenoid generator before.

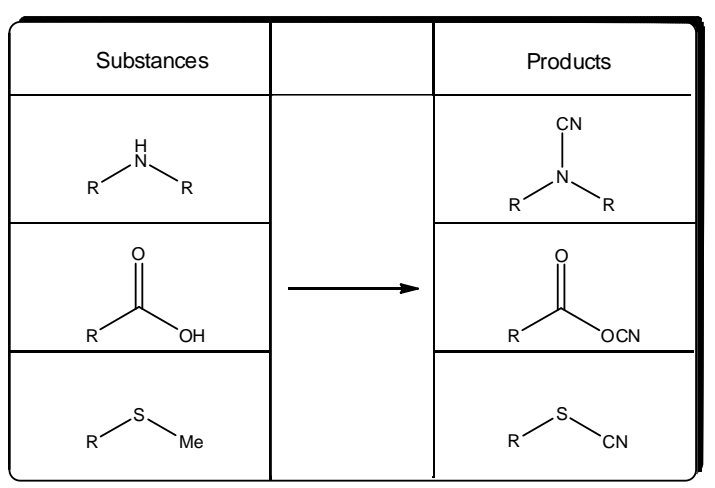

Scheme 1: Common reactions of cyanogen bromide

\section{RESULTS AND DISCUSSION}

In this paper a new reaction of active carbons (1a-j) with cyanogen bromide in the presence of an organic base (triethyl amine or pyridine in some cases) has been described. Generated active carbenoids (2a-j) are shown in Scheme 2. Recently, we have performed the condensation of (thio)barbituric acids (1a-d) with aldehydes ${ }^{22}$ and ketones ${ }^{23}$ in the presence of $\mathrm{BrCN}$ and $\mathrm{Et}_{3} \mathrm{~N}$ afforded spiro[furo[2,3- $d$ ]pyrimidine-6,5_pyrimidine]pentaones and active carbenoid salt (2ad). In the reaction of 5,5-dimethylcyclohexane-1,3dione (dimedone, 1e) under same condition the similar scaffold structures have been produced as expected ${ }^{24}$. Also we have investigated the condensation of Meldrum's acid (1f) with aldehydes in the presence of $\mathrm{BrCN}$ and $\mathrm{Et}_{3} \mathrm{~N}$ under the same condition. In this reaction, full-substituted cyclopropanes and the salt of $\mathbf{2} \mathbf{f}$ were obtained ${ }^{25,26}$.

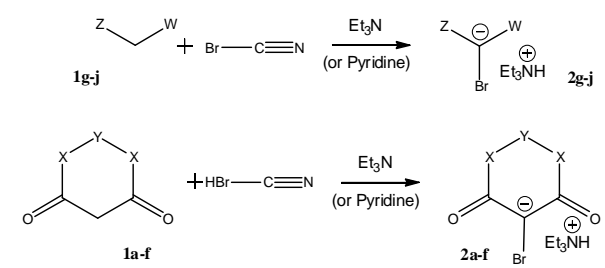

X-Y-X= NH-CO-NH (a); MeN-CO-NMe (b); HN-CSNH (c); MeN-CO-NH (d); $\mathrm{CH}_{2}-\mathrm{CMe}_{2}-\mathrm{CH}_{2}$ (e); O-CMee- $\mathrm{O}$ (f) $\mathrm{Z}, \mathrm{W}=\mathrm{CN}, \mathrm{CN}(\mathrm{g}) ; \mathrm{EOO}-\mathrm{CO}, \mathrm{CO}_{2} \mathrm{Et}(\mathrm{h})$; EtO-CO, CN (i); $\mathrm{MeCO}, \mathrm{CO}_{2} \mathrm{Et}(\mathrm{j})$

Scheme 2: Reaction of active carbons with cyanogen bromide in the presence of TEA

On the other hand based on our earlier experiments, we decided to investigate on the possibility of the reaction of non-cyclic active carbons. For this reason some reactions of cyanogen bromide and triethyl amine with acyclic active carbons (19-j) were performed ${ }^{25,26}$. Although we did not attain triethylammonium 2-bromo-1,3diethoxy-1,3-dioxopropan-2-ide (2h) obtained from diethyl malonate reaction (and other acyclic active carbon), we have succeeded in obtaining triethylammonium bromodicyanomethanide $(\mathbf{2 g})$ in the latter case malononitrile. Perhaps it is due to the stronger electron-attracting nature of cyanide group versus ester and/or simple carbonyl groups. By the way cyanide group has less steric hindrance than ester or carbonyl groups. 
Proposed mechanism has been explained in Scheme 3. On the basis of the well established chemistry of pyrimidines ${ }^{27}$ and according to the mechanism of the bromination of 1-alkyl imidazoles by cyanogen bromide ${ }^{28}$ it is reasonable to assume that active carbons 1a-f reacted with cyanogen bromide and formed alkyl carbonobromidoimidate 3a-f. Intramolecular rearrangement of 3a-f afforded 4a-f followed by loss of HCN. Triethylamine as a base captured the acidic methylene proton of $\mathbf{4 a - f}$ and salts of $\mathbf{2 a - f}$ were formed. The salt of triethylammonium hydrobromide was also observed. Unfortunately, all attempts failed to separate or characterize $\mathbf{3 a - f}$ and $\mathbf{4 a - f}$ intermediates as representatives.

In the case of malononitrile a similar mechanism has been suggested (scheme 4).

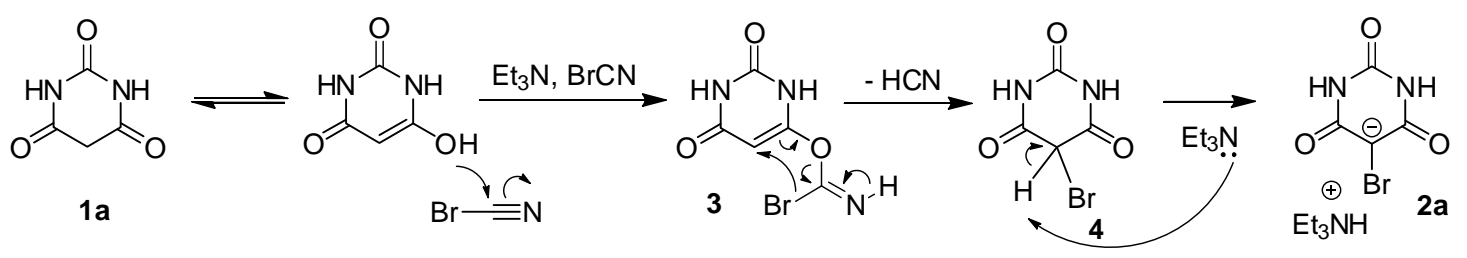

Scheme 3: Proposed mechanism of 2a formation

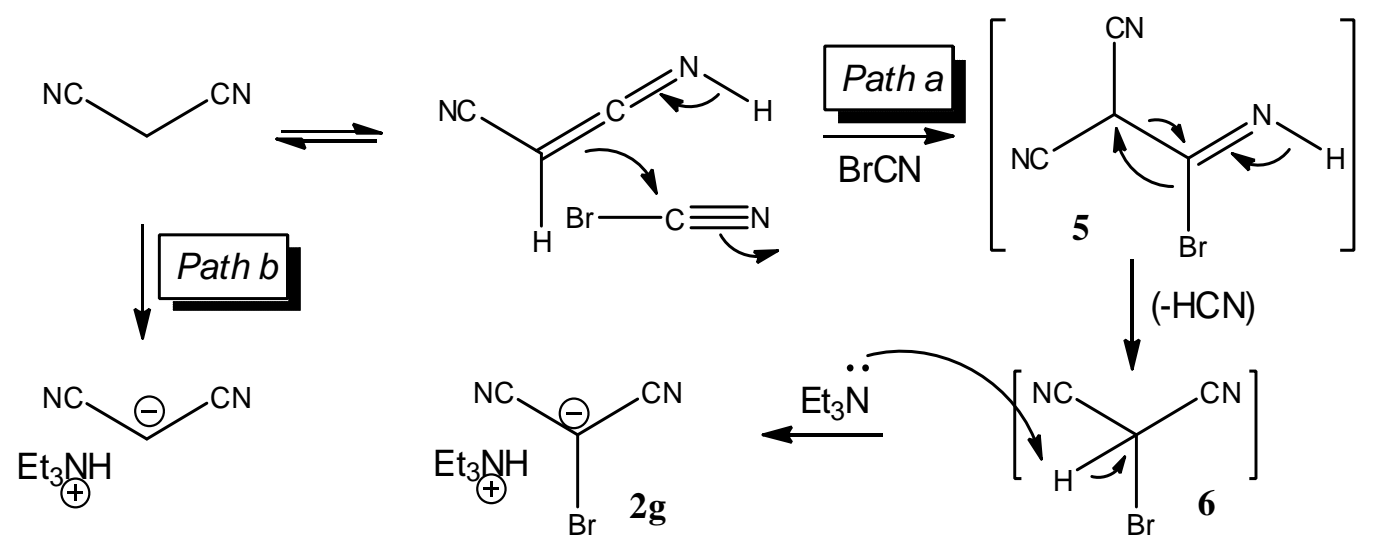

Scheme 4: Proposed mechanism of $2 \mathrm{~g}$ formation

It is reasonable to assume that the compound $\mathbf{1 g}$ reacts directly with cyanogen bromide to form 2,2-dicyanoacetimidoyl bromide (5) intermediate through path a. Intramolecular rearrangement of this intermediate produces 2bromomalononitrile (6) intermediate. Finally, triethylamine as a base captures the acidic proton affording $\mathbf{2 g}$. Malononitrile $(\mathbf{1 g})$ directly reacts with triethylamine to form the salt of triethylammonium dicyanomethanide in the absence of cyanogen bromide (path $b$ ). The salt of triethylammonium dicyanomethanide was also separated and characterized in direct reaction of $\mathbf{1 9}$ with triethylamine through path $b$.

All attempts to isolation of $\mathbf{5}$ and $\mathbf{6}$ were unsuccessful unfortunately. According to our search, there is no report about compound $\mathbf{2} \mathbf{g}$ in literatures. The salt of $\mathbf{2} \mathbf{g}$ was isolated and characterized by spectroscopy techniques. Other evidence for the formation and confirmation of $\mathbf{2} \mathbf{g}$ (the existence of bromine atom in this salt structure) was performed by Beilstein test and the wet silver nitrate test (precipitate of pale yellow silver bromide). 
The IR spectrum of $\mathbf{2} \mathbf{g}$ shows the frequency of $\mathrm{NH}+$ stretching at the broad range of 2500-3300 cm-1, frequency of $\mathrm{CN}$ and $\mathrm{C}-\mathrm{Br}$ stretching at 2167 and $565 \mathrm{~cm}-1$, respectively. The 1 HNMR spectrum of this compound shows (integration in parenthesis) a triplet at ' $1.39 \mathrm{ppm}$ $(9 \mathrm{H})$ and a multiplet (a quartet approximately) at $3.14 \mathrm{ppm}(6 \mathrm{H})$ are corresponding to methyl and methylene protons in triethylammonium salt moiety, respectively. A broad singlet at ${ }^{\prime} 9.78 \mathrm{ppm}(1 \mathrm{H})$ is of $\mathrm{NH}+$ in this salt. ${ }^{13} \mathrm{C}$ NMR spectrum of this salt shows four distinct peaks that confirm the structure of $\mathbf{2 g}$. The structure of the 2a-f was deduced from their IR, ${ }^{1} \mathrm{H}$ NMR, ${ }^{13} \mathrm{C}$ NMR spectra and $\mathrm{CHN}$ analysis. Representatively, the ${ }^{1} \mathrm{H}$ NMR spectrum of $\mathbf{2 a}$ consisted of a triplet for three methyl protons at ' $1.16 \mathrm{ppm}$, a quartet for the corresponding methylene protons at $3.08 \mathrm{ppm}$, a broad singlet for ammonium proton at ${ }^{\prime} 8.93 \mathrm{ppm}$ and a singlet for two amide protons at ' $9.38 \mathrm{ppm}$ on barbituric acid ring moiety. The IR spectrum of $2 \mathbf{a}$ indicated no $\mathrm{CN}$ bond stretching absorption. The ${ }^{13} \mathrm{C}$ NMR spectrum of $\mathbf{2 a}$ showed five distinct peaks. The peak at $\delta 9.09$ and $46.19 \mathrm{ppm}$ are of methyl and methylene carbons in triethylammonium salt moiety, respectively and the peak at $72.27 \mathrm{ppm}$ corresponds to C-5 on barbituric acid ring. Two peaks at' 152.02 and 161.26 ppm correspond to the carbonyl groups on barbituric acid ring moiety, respectively. Other evidence for the formation of 2a-f (the existence of bromine atom in these molecules) was performed by Beilstein test and the wet silver nitrate tes ${ }^{29}$ (precipitate of pale yellow silver bromide). During isolation and identification of 2a-f interestingly there is not any evidence of cyanide peak in IR spectra (scheme 5).<smiles>[X][X]C(=O)CC([X])=O</smiles>

1a-f<smiles>CCN(Br)CCCCCCCC#N</smiles>

$1 \mathrm{~g}$<smiles>[X]C(=O)C(C#N)C(=O)O</smiles>

\section{Scheme 5: Reaction path through cyanation of active carbon}

In the case of Barbituric acid's salts, $\mathbf{2} \mathbf{b}$ plays an important role and its nucleophilicity is stronger than that of $\mathbf{2} \mathbf{a}$ and $\mathbf{2 c}$. The $\mathbf{2 a}$ and $\mathbf{2 c}$ have aromatic nature with delocalizing of the negative charge while $\mathbf{2 b}$ has not.

Acyclic compounds with the exception of malononitrile behave in different way. Reason of this different behavior is not clearly recognized. Perhaps it is due to the enol-keto equilibrium occurred in acyclic beta-dicarbonyl or betacyanocarbonyl compounds (scheme 6). For example ethyl aceto acetate mainly exists in beta- keto 1-en 1-ol (12j) form and not in beta dicarbonyl (1j) form. Whereas cyclic compounds like Barbituric acid, Dimedone and Meldrum's acid (1a-f) have been founded mainly in keto form. A similar equilibrium is not seen in malononitrile (scheme 7). Bromodicyanomethanide $(\mathbf{2 g})$ is the main form. Any symptom of other resonance forms is not seen in ${ }^{13}$ CNMR spectra of $\mathbf{2} \mathbf{g}$ as expected. Also as seen in figure 2 , three distinctive peaks for $\mathbf{2} \mathbf{a}$ and two peaks for ammonium ion are shown in ${ }^{13} \mathrm{CNMR}$ spectrum. There is not any symptom of existence of enol form for $2 a$.<smiles>CCO/C(O)=C/C(C)=O</smiles>

12j

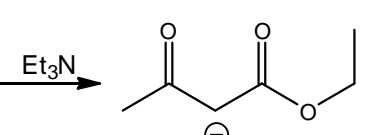
9j

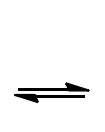

Minor form<smiles>CCO/C([O-])=C/C(C)=O</smiles>

10j

Major form<smiles>CCOC(=O)/C=C(/C)[O-]</smiles>

11j

Major form

Scheme 6: Resonance forms in ethyl aceto acetate $1 \mathrm{j}$ and 1-ethoxy-1,3-dioxobutan-2-ide (9j) 
Reaction of diethyl malonate (DEM) (1h), ethyl cyanoacetate (ECA) (1i) and ethyl acetoacetate (EAA) (1j) with cyanogen bromide in acetone formed diethyl bromomalonate (13h) and ethyl bromoacetoacetate (13j) in moderate yield, respectively. Triethylammonium hydrobromide salt was observed in all reaction products (scheme 8).

The ${ }^{1} \mathrm{H}$ NMR spectrum of diethyl bromomalonate, $13 \mathrm{~h}$ show a triplet at ' 1.31 and a quartet at' $4.29 \mathrm{ppm}$ are of to equivalent methyl and methylene protons, respectively. A singlet at' 4.82 corresponds to the $\mathrm{CHBr}$ proton. The peak integration ratios 1.0:4.0:6.0 are of methine, two methylene and two methyl protons, respectively. These ratios are in good agreement with the structure of $13 \mathrm{~h}$. The ${ }^{13} \mathrm{C}$ NMR spectrum of $13 \mathrm{~h}$ show a peak at ' 13.85 and $63.21 \mathrm{ppm}$ are of methyl and methylene carbon atoms, at ' 42.40 and 164.58 ppm corresponds to the methine and carbonyl carbon atoms respectively. Diethyl cyanomalonate, $8 \mathrm{~h}$ has been synthesized previously by the reaction of ethyl cyanoacetate, 1i with ethyl chloroformate in acetone ${ }^{30}$. We performed the reaction of $1 \mathrm{~h}$ with cyanogen bromide according to method of reference 30 (formation of $\mathbf{8 h}$ was not observed).<smiles>N#C[C-]=CC#N</smiles><smiles>CC(C)(C)C</smiles><smiles>N#CC1CN2CC1O2</smiles>

Scheme 7: Possible resonance form of dicyanomethanide $(2 \mathrm{~g})$

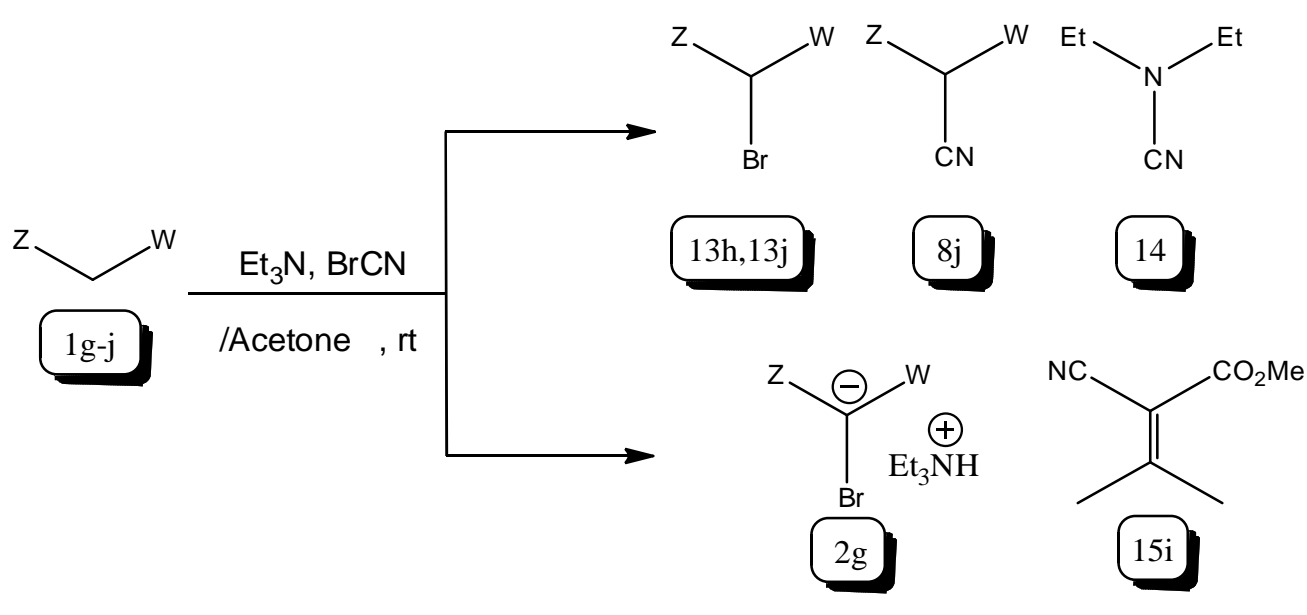

$\mathrm{Z}, \mathrm{W}=\mathrm{CN}, \mathrm{CN}(\mathrm{g}) ; \mathrm{EtO}-\mathrm{CO}, \mathrm{CO}_{2} \mathrm{Et}(\mathrm{h}) ; \mathrm{EtO}-\mathrm{CO}, \mathrm{CN}(\mathrm{i}) ; \mathrm{MeCO} \mathrm{CO}_{2} \mathrm{Et}(\mathrm{j})$

Scheme 8: Acyclic compounds reaction with cyanogen bromide

In contrast, our experiments indicated that the reaction of $\mathbf{l} \mathrm{h}$ with cyanogen bromide leads to diethyl bromomalonate, $13 \mathrm{~h}$ and $\mathrm{N}, \mathrm{N}$ diethylcyanamide (14) in acetone (Scheme 9).

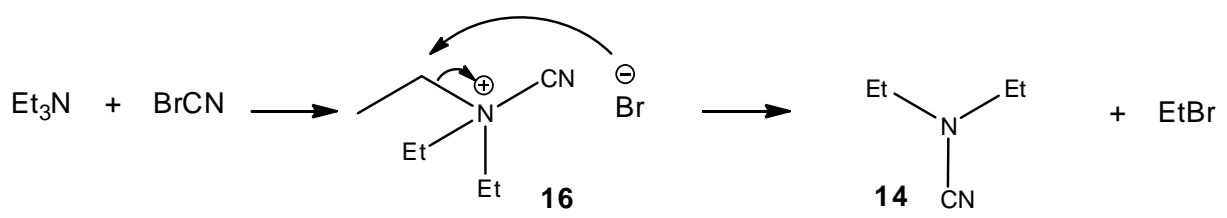

Scheme 9: Formation mechanism of 14

Expectedly, triethylamine attacks the $\mathrm{NC}^{+}$

of cyanogen bromide obtaining triethylcyanoammonium bromide salt (16) (Scheme
9). According to Scheme 9, the ethyl bromide and 14 were observed based on von Braun reaction through analyzing the crude reaction mixture by 
GC-Mass analyses. The reaction of ethyl cyanoacetate, $1 \mathbf{i}$ with cyanogen bromide in ether indicated no significant product(s). In contrast, in acetone as a polar aprotic solvent ethyl 2isopropylidenecyanoacetate (15i) was afforded by means of the condensation of $1 \mathbf{i}$ with acetone in $32 \%$ yield (Scheme 8). No $13 i$ and $8 \mathrm{i}$ were observed in this reaction.

The structure of $15 i$ was characterized by ${ }^{1}$ HNMR, ${ }^{13}$ CNMR and GC-Mass analysis. Interestingly, ethyl bromoacetoacetate, $\mathbf{1 3 j}$ or ethyl cyanoacetoacetate, $\mathbf{8 j}$ were found in the reaction of ethyl acetoacetate, $1 \mathbf{j}$ and cyanogen bromide in ether as solvent (Scheme 8).

For assurance of existence of free carbenoid, in the case of malononitrile we have performed some of well-known carbenes reactions.
Entrapping of free carbenes by polar carbon-carbon double bonds (producing cyclopropane structure) is one of the most famous reactions used to identification of carbenes. Entrapping includes the shuttle attack of carbene to polar carbon-carbon double bond. Two moles of malenonitrie were reacted with aldehydes $17 \mathrm{k}-\mathbf{z}$ as knovenagel condensation (insitu performing of $\mathbf{1 8 k - z}$ ). On the other hand malononitrile was reacted with trithylamine and cyanogen bromide as described before. Negative charge of $\mathbf{2} \mathbf{g}$ attacks to polar double bond of $\mathbf{1 8 k - z}$ as shown in the scheme 10 . Final cyclopropane products $19 \mathrm{k}-\mathrm{z}$ were isolated and identified by ${ }^{1} \mathrm{HNMR},{ }^{13} \mathrm{CNMR}$ and IR data. Existence of free carbene was maintained by results. The same method for entrapping of carbenes in the case of cyclic substrates resulted similar cyclopropanes as expected.

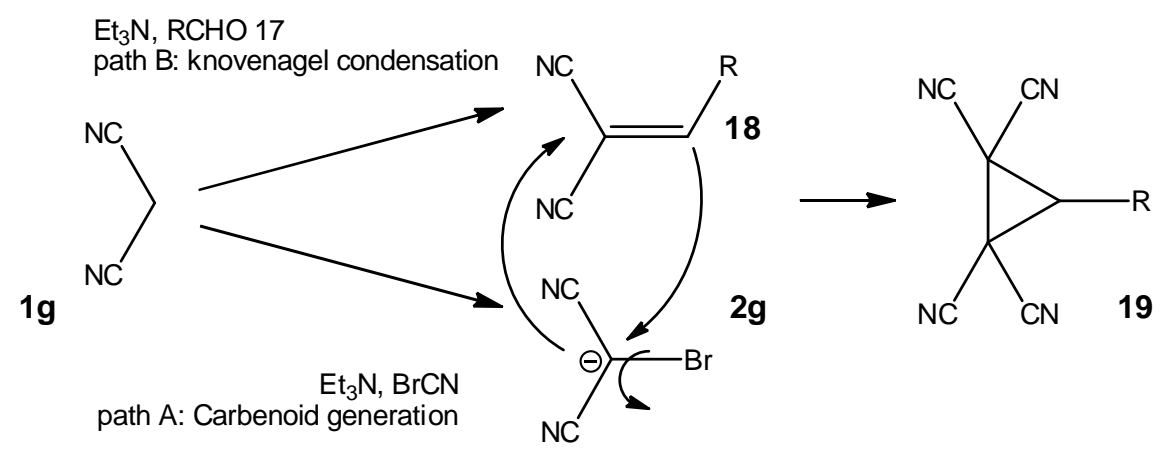

$\mathrm{R}=\mathrm{C}_{6} \mathrm{H}_{5}(\mathbf{k}), \mathrm{R}=0-\mathrm{O}_{2} \mathrm{~N}-\mathrm{C}_{6} \mathrm{H}_{4}(\mathbf{l}), \mathrm{R}=m-\mathrm{O}_{2} \mathrm{~N}-\mathrm{C}_{6} \mathrm{H}_{4}(\mathbf{m}), \mathrm{R}=p-\mathrm{Br}-\mathrm{C}_{6} \mathrm{H}_{4}(\mathbf{n}), \mathrm{R}=p-\mathrm{Cl}-\mathrm{C}_{6} \mathrm{H}_{4}(\mathbf{o})$, $\mathrm{R}=3,4,5-\mathrm{Tri}-\mathrm{CH}_{3} \mathrm{O}-\mathrm{C}_{6} \mathrm{H}_{2}(\mathbf{p}), \mathrm{R}=m-\mathrm{PhO}-\mathrm{C}_{6} \mathrm{H}_{4}(\mathbf{q}), \mathrm{R}=p-\mathrm{CH}_{3} \mathrm{O}-\mathrm{C}_{6} \mathrm{H}_{4}(\mathbf{r}), \mathrm{R}=p-\mathrm{NC}_{-}-\mathrm{C}_{6} \mathrm{H}_{4}(\mathbf{s})$, $\mathrm{R}=0$-Naphthyl (t), $\mathrm{R}=2$-Furyl (u), $\mathrm{R}=$ 2-Pyridyl (v), $\mathrm{R}=$ 9-Anthranyl $(\mathbf{w}), \mathrm{R}=$ 2-Pyrrolyl $(\mathbf{x})$, $\mathrm{R}=p-\mathrm{OH}-\mathrm{C}_{6} \mathrm{H}_{4}(\mathbf{y}), \mathrm{R}=m-\mathrm{OH}-\mathrm{C}_{6} \mathrm{H}_{4}(\mathbf{z})$

\section{Scheme 10: Insitu generation of carbene based on malononitrile}

\section{EXPERIMENTAL}

\section{General procedures}

Melting points were measured with a digital melting point apparatus (Electrothermal) and were uncorrected. IR spectra were determined in the region $4000-400 \mathrm{~cm}^{-1}$ on a NEXUS $670 \mathrm{FT}$ IR spectrometer by preparing $\mathrm{KBr}$ pellets. The ${ }^{1} \mathrm{HNMR}$ and ${ }^{13} \mathrm{CNMR}$ spectra were recorded on Bruker 300 FT-NMR at 300 and $75 \mathrm{MHz}$, respectively (Urmia University, Urmia, Iran). ${ }^{1} \mathrm{HNMR}$ and ${ }^{13} \mathrm{CNMR}$ spectra were obtained on solution in DMSO- $d_{6}$ and/or in $\mathrm{CDCl}_{3}$ as solvents using TMS as internal standard.
The data are reported as ( $\mathrm{s}=$ singlet, $\mathrm{d}=$ doublet, $\mathrm{t}=$ triplet, $\mathrm{q}=$ quartet, $\mathrm{m}=$ multiplet or unresolved, bs=broad singlet, coupling constant(s) in $\mathrm{Hz}$, integration). All reactions were monitored by TLC with silica gel-coated plates (solvent system of most cases is AcOEt:AcOH/ 80:20/ v:v). Elemental analyses were performed using a VarioEL III analyzer (Tabriz University, Tabriz, Iran). The mass analysis performed using mass spectrometer (Agilent Technology (HP) type, MS Model: 5973 ,ion source temperature was $230 \stackrel{\circ}{ } \mathrm{C}$ (Tehran University, Tehran, Iran). 
Synthesis of 2, Method A: In a $25 \mathrm{~mL}$ round bottom flask equipped by a magnetically stirrer, dissolved $0.12 \mathrm{~g}(0.96 \mathrm{mmol})$ cyanogen bromide $(\mathrm{BrCN})$ in 4 $\mathrm{mL}$ ethanol at $0{ }^{\circ} \mathrm{C}$. Then separately, $0.15 \mathrm{~g}(0.96$ $\mathrm{mmol}$ ) barbituric acid were dissolved in $10 \mathrm{~mL}$ ethanol in an Erlenmeyer, $0.75 \mathrm{~mL}$ triethylamine was added into solution and then was transferred it into a separatory funnel, then it was added drop wise into solution of $\mathrm{BrCN}$ in round bottom flask at $0{ }^{\circ} \mathrm{C}$. The progression of reaction was monitored by thin layer chromatography (TLC). After a few minutes, the white-cream solid precipitate, filtered off, washed with few $\mathrm{mL}$ ethanol and dried.

\section{Method B}

In a $10 \mathrm{~mL}$ with Teflon-faced screw cap tube equipped by a magnetically stirrer, dissolved, $0.132 \mathrm{~g}(2 \mathrm{mmol})$ malononitrile, $0.202 \mathrm{~g}(2 \mathrm{mmol})$ triethylamine in $5 \mathrm{~mL}$ ethanol and then $0.210 \mathrm{~g} \mathrm{(2}$ $\mathrm{mmol}$ ) cyanogen bromide (BrCN) was added into solution at $0{ }^{\circ} \mathrm{C}$. White-Cream color solid precipitate in less than five minutes, filtered off and washed with few $\mathrm{mL}$ ethanol and dried.

\section{Synthesis of cyclopropane structures}

In a $10 \mathrm{~mL}$ with Teflon-faced screw cap tube equipped by a magnetically stirrer, dissolved,

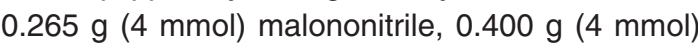
triethylamine and $2 \mathrm{mmol}$ aldehydes in $7 \mathrm{~mL}$ ethanol and then $0.210 \mathrm{~g}(2 \mathrm{mmol})$ cyanogen bromide (BrCN) was added into solution at $0{ }^{\circ} \mathrm{C}$. temprator was raised to $70{ }^{\circ} \mathrm{C}$. Cream color solid precipitate after a few minutes, filtered off and washed with few $\mathrm{ml}$ ethanol and dried.

The physical and spectral data of the selected compounds are follows as representatives. Spectral data for intermediate compounds (which prepared for study of mechanism) have not been described. Do not hesitate to ask for full supplementary data or more information.

Triethylammonium-5-bromo-2,4,6-trioxohexahy dropyrimidin-5-ide (2a)

White solid $(50 \%) ; \mathrm{mp}=155-158{ }^{\circ} \mathrm{C}$ (decomps.); FT-IR (KBr) 3130, 2985, 2816, 1658 $(\mathrm{C}=\mathrm{O}), 603,524$ (C-Br) cm-1; ${ }^{1} \mathrm{H}$ NMR (DMSO-d $300 \mathrm{MHz}) \delta 1.16\left(\mathrm{t}, 9 \mathrm{H}, 3 \mathrm{CH}_{3}\right), 3.08\left(\mathrm{q}, 6 \mathrm{H}, 3 \mathrm{CH}_{2}\right)$, 8.93 (bs, $1 \mathrm{H}, \mathrm{NH}$ ammonium), 9.38 (s, 2H, $2 \mathrm{NH}$ BA); ${ }^{13} \mathrm{C}$ NMR (DMSO-d 6 , $75 \mathrm{MHz}$ )' 161.3, 152.0,
72.3, 46.2, 9.1; Anal. Calcd. for $\mathrm{C}_{10} \mathrm{H}_{18} \mathrm{~N}_{3} \mathrm{O}_{3} \mathrm{Br}$ : C, 38.9; N, 13.63; H, 5.84. Found: C, 39.04; N, 13.66; $H$, $5.92 \%$. MS, m/z $308\left(\mathrm{M}^{+}, 0\right), 154$ (7), 128 (base peak, 100), 101 (15), 86 (60), 72 (5), 58 (16), 42 (98).

Triethylammonium-1,3-dimethyl-5-bromo-2,4,6trioxohexahydropyrimidin-5-ide (2b)

White solid (45\%); mp 152-154 ${ }^{\circ} \mathrm{C}$ (decamps.). FT-IR (KBr) 3200, 2980, 1670, $526 \mathrm{~cm}$ '; ${ }^{1} \mathrm{H}$ NMR (DMSO-d, $\left.300 \mathrm{MHz}\right){ }^{\prime} 1.17(\mathrm{t}, 9 \mathrm{H}), 2.80$ (s, 6H), 3.08 (q, 6H), 8.95 (bs, $1 \mathrm{H}) ;{ }^{13} \mathrm{C}$ NMR (DMSOd6, $75 \mathrm{MHz}$ ) ' 161.9, 157.1, 73.4, 46.1, 30.2, 9.1; Anal. Calcd. for $\mathrm{C}_{12} \mathrm{H}_{22} \mathrm{~N}_{3} \mathrm{O}_{3} \mathrm{Br}: \mathrm{C}, 42.87 ; \mathrm{N}, 12.50 ; \mathrm{H}$, 6.60. Found: C, 42.65; N, 12.43; H, 6.52\%.

Triethylammonium-5-bromo-4,6-dioxo-2thioxohexahydropyrimidin-5-ide (2c)

White solid (50\%); $\mathrm{mp}=159-161^{\circ} \mathrm{C}$; FT-IR (KBr) 3408, 3070, 2975, 2937, 2677, 1648 (C=O), 1612, 590, 526 (C-Br) cm-1; ${ }^{1} \mathrm{H}$ NMR (DMSO-d, 300 $\mathrm{MHz})^{\prime} 1.16\left(\mathrm{t}, 9 \mathrm{H}, 3 \mathrm{CH}_{3}\right), 3.07$ (q, $\left.6 \mathrm{H}, 3 \mathrm{CH}_{2}\right), 10.17$ (bs, 1H, NH ammonium), 10.35 (bs, 2H, 2NH TBA); ${ }^{13} \mathrm{C}$ NMR (DMSO-d, $\left.75 \mathrm{MHz}\right)$ ' 174.7, 164.3, 79.7, 46.2, 9.1; Anal. Calcd. for $\mathrm{C}_{10} \mathrm{H}_{18} \mathrm{~N}_{3} \mathrm{O}_{2} \mathrm{SBr}$ : C, 37.05; $\mathrm{N}, 12.97 ; \mathrm{H}, 5.56$. Found: C, 37.10; N, 13.05; H, 5.51 $\%$.

Triethylammonium-2-bromo-5,5-dimethylcyclo hexane-1,3-dione-2-ide (2e)

Colorless crystalline solid (62\%); $\mathrm{mp}=75$ $76^{\circ} \mathrm{C}$; FTIR $\left(\mathrm{KBr}, \mathrm{Cm}^{-1}\right) \mathrm{v}_{\text {max }}: 3417,2958,2870,2678$, 2495, 1644, 1610, 1509, 472; ${ }^{1} \mathrm{H}$ NMR $\left(\mathrm{CDCl}_{3}, 300\right.$ $\mathrm{MHz}) \delta 7.27$ (bs, 1H), 3.02 (q, J=7.5 Hz, 6H), 2.18 (s, 4H), 1.17 (t, J=7.5 Hz, 9H), $0.87(\mathrm{~s}, 6 \mathrm{H}) ;{ }^{13} \mathrm{C}$ NMR $\left(\mathrm{CDCl}_{3}, 75 \mathrm{MHz}\right)^{\prime}$ ' 8.7, 28.3, 31.7, 46.2, 50.2, 96.7, 186.0.

Triethylammonium 5-bromo-2,2-dimethyl-4,6dioxo-1,3- dioxan-5-ide (2f)

White crystalline solid (45\%), mp 252-253

${ }^{\circ} \mathrm{C}$; IR (KBr) $3448(\mathrm{OH}), 2995,2944,2738,2678$

(CH-aliph.), $1752(\mathrm{C}=\mathrm{O}), 1033(\mathrm{C}-\mathrm{O}), 752(\mathrm{C}-\mathrm{Br})$ $\mathrm{cm}^{-1} ;{ }^{1} \mathrm{H}$ NMR $\left(\mathrm{CDCl}_{3}, 300 \mathrm{MHz}\right)$ ' 10.10 (bs), 3.09 (q, 6H), $1.54(\mathrm{~s}, 6 \mathrm{H}), 1.27(\mathrm{~s}, 9 \mathrm{H}) ;{ }^{13} \mathrm{C} \mathrm{NMR}\left(\mathrm{CDCl}_{3}\right.$, $75 \mathrm{MHz}) \delta$ 164.0, 102.2, 46.4, 27.5, 25.6, 8.7.

Triethylammonium bromodicyanomethanide $(2 \mathrm{~g})$ White crystalline solid (60); FT-IR ( $\mathrm{KBr}$ ) 3420, 3047, 2987, 2947, 2804, 2738, 2678, 2491, 
2167, 1475, 1035, $565 \mathrm{~cm}^{-1} ;{ }^{1} \mathrm{H}$ NMR (CDCl3, 300 $\mathrm{MHz}) \delta 1.39(\mathrm{t}, 9 \mathrm{H}, \mathrm{J}=7.2 \mathrm{~Hz}), 3.14(\mathrm{~m}, 6 \mathrm{H}), 9.78$ (bs, $1 \mathrm{H}) ;{ }^{13} \mathrm{C}$ NMR $(\mathrm{CDCl} 3,75 \mathrm{MHz})$ ' $141.6,121.6$, 46.6, 8.8 .

\section{Diethyl bromomalonate (13h)}

The experimental procedure for the reaction of $\mathbf{1 h}, \mathbf{1 i}$ and $\mathbf{1 j}$ with cyanogen bromide and triethylamine in acetone and other solvents were similar to the barbituric acid experimental procedure (method $A)$. Colorless oily liquid $(38 \%)$. FT-IR (KBr) 2985, 1743, $1150 \mathrm{~cm}^{-1}$; ${ }^{1} \mathrm{H}$ NMR (DMSO$\left.\mathrm{d}_{6}, 300 \mathrm{MHz}\right): \delta 1.31(\mathrm{t}, 6 \mathrm{H}), 4.29(\mathrm{q}, 4 \mathrm{H}), 4.82(\mathrm{~s}$, $1 \mathrm{H}) .{ }^{13} \mathrm{C}$ NMR (DMSO-d, $75 \mathrm{MHz}$ ); ' 164.6, 63.2, 42.4, 13.9; GCMS m/z: (RT, $3.96 \mathrm{~min}$.), $241(\mathrm{M}+2)$, 239 (M), 212 (2), 193 (10), 166 (18), 140 (30), 138 (42), 120 (20), 29 (100, base peak).

\section{3-phenylcyclopropane-1,1,2,2-tetracarbonitrile} (19k)

White crystalline solid (65\%), mp 225-227 ${ }^{\circ} \mathrm{C}$ (decompds.) (lit. 229-230 ${ }^{\circ} \mathrm{C} 10$ ); FT-IR (KBr) 3046, 3013, 2928, 2264, 1640, 1374, 1231, 741, 701, 662 $\mathrm{cm}^{-1} ;{ }^{1} \mathrm{H}^{\mathrm{NMR}}\left(\mathrm{DMSO}-\mathrm{d}_{6}, 300 \mathrm{MHz}\right){ }^{\prime} 5.29(\mathrm{~s}, 1 \mathrm{H})$, $7.47(\mathrm{~m}, 3 \mathrm{H}), 7.78(\mathrm{~m}, 2 \mathrm{H}) ;{ }^{13} \mathrm{C}$ NMR (DMSO- $\mathrm{d}_{6}, 75$ $\mathrm{MHz}) \delta 130.4,130.0,129.4,127.3,111.4,109.9$, 42.2, 23.6 . 3-(2-nitrophenyl)cyclopropane-1,1,2,2tetracarbonitrile (19l)

White crystalline solid (60\%), mp 215-216 ${ }^{\circ} \mathrm{C}$ (decompds.); FT-IR (KBr) 3108, 3089, 3031, 2924, 2866, 2258, 1610, 1530, 1346, 851, 794, 736, 702 $\mathrm{cm}^{-1}{ }^{1}{ }^{1} \mathrm{H}$ NMR (Acetone- $\left.\mathrm{d}_{6}, 300 \mathrm{MHz}\right)^{\prime} 5.45(\mathrm{~s}, 1 \mathrm{H}$ ), $7.96(\mathrm{t}, 1 \mathrm{H}, \mathrm{J}=7.5 \mathrm{~Hz}), 8.07(\mathrm{t}, 1 \mathrm{H}, \mathrm{J}=7.5 \mathrm{~Hz}), 8.37$ $(\mathrm{d}, 1 \mathrm{H}, \mathrm{J}=7.5 \mathrm{~Hz}), 8.51(\mathrm{~d}, 1 \mathrm{H}, \mathrm{J}=7.5 \mathrm{~Hz}) ;{ }^{13} \mathrm{C}$ NMR (Acetone- $\mathrm{d}_{6}, 75 \mathrm{MHz}$ ) '147.9, 135.3, 132.7, 132.6, 126.6, 122.0, 110.2, 108.8, 41.7, 23.8.

3-(3,4,5-Trimethoxyphenyl)cyclopropane-1,1,2,2tetracarbonitrile (19p)

W hite crystalline solid (68\%), mp 227-229 ${ }^{\circ} \mathrm{C}$ (decompds.); FT-IR (KBr) 3047, 2997, 2943, 2842, 2260, 1592, 1512, 1468, 1421, 1251, 1127, 993 $\mathrm{cm}^{-1} ;{ }^{1} \mathrm{H}$ NMR (Acetone- $\mathrm{d}_{6}, 300 \mathrm{MHz}$ ) ' $3.77(\mathrm{~s}, 3 \mathrm{H}$ ), $3.87(\mathrm{~s}, 6 \mathrm{H}), 4.96(\mathrm{~s}, 1 \mathrm{H}), 7.31(\mathrm{~s}, 2 \mathrm{H}) ;{ }^{13} \mathrm{C}$ NMR (Acetone- $d_{6}, 75 \mathrm{MHz}$ ) $\delta 153.9,139.8,121.4,110.7$, 109.1, 107.2, 59.8, 55.9, 42.9, 22.9.

\section{ACKNOWLEDGEMENTS}

The Authors gratefully acknowledge financial support by the Research Council of Islamic Azad University-Ahar Branch.

\section{REFERENCES}

1. Lee, B. H.; Clothier, M. F.; Pickering, D. A. Tetrahedron lett. 1997, 38, 6119-6122.

2. Bishop P., Chmielewski J. Tetrahedron lett. 1992, 33, 6263-6266.

3. Kumar, V. Synlett. 2005, 10, 1638-1639.

4. Hartmann, W. W.; Dreger, E. E. Org. Syn. Coll. Vol. 2; John Wiley: London, (1943).

5. (a) Podesva, C. P.; Tarlton, E. J.; McKay, A. P. Can. J. Chem. 1962, 40, 1403-1407. (b) Deaton, D. N.; Hassell, A. M.; McFadyen, R. B.; et al. Bioorg. Med. Chem. Lett. 2005, 15, 1815-1819.

6. Snider, B. B.; O'Hare, S. M. Tetrahedron Lett. 2001, 42, 2455-2458.

7. Cai, T.; Xian, M.; Wang, P. G. Bioorg. Med. Chem. Lett. 2002, 12, 1507-1510.

8. Scholl, R.; Kacer, F. Ber. Dtsch. Chem. Ges. 1903, 36, 322-331.

9. Ho, J.-L.; Wong, C. M. Synth. Commun. 1973,
3, 63-66.

10. von Braun, J.; Engelbertz, P. Ber. Dtsch. Chem. Ges. 1923, 56, 1573-1577.

11. (a) Gross, E.; Witkop, B. J. Am. Chem. Soc. 1961, 83, 1510-1511. (b) Stadtmana, E. R.; Van Remmen, H.; Richardson, A.; et al. Biochim. Biophys. Acta 2005, 1703, 135-140.

12. Zhong, H.; Marcus, S. L.; Li, L. J. Am. Soc. Mass Spectrom. 2005, 16, 471-481.

13. Casy A.F., Hassan M.M.A., Tetrahedron let. 1967, 23, 4075-4086.

14. Martin, D.; Bauer, M. Org Synth Coll. Vol. 7, p435. (1990)

15. Gross, E.; Witkop, B. J. Am. Chem. Soc. 1961, 83, 1510-1511.

16. McCallum, PBW.; Grimmett, MR.; Blackman, AG. Aust. J. Chem. 1999, 52, 159-166.

17. Tanner, DD.; Lycan, G.; Bunce, NJ. Can. J. Chem. 1970, 48, 1492-1497. 
18. Alberola, A.; Andres, C.; Ortega, AG.; Pedrosa, R.; Vicente, M. Synth Commun.1986, 16, 1161-1165.

19. Organic Syntheses, Coll. Vol. 3, p.608 (1955); Vol. 27, (1947).

20. Hageman, H. A. The von Braun Reactions, In Organic Reactions, Vol. 7; Blatt, A. H.; Cope, A. C.; McGrew, F. C.; Niemann, C.; Snyder, A., Eds.; Wiley: New York, (1953).

21. Furuya, S.; Okamoto, T. Heterocycles. 1988, 27, 2609-2618.

22. Jalilzadeh, M.; Noroozi Pesyan, N.; Rezaee, F.; Rastgar, S.; Hosseini, Y.; ^ahin, E. Mol. Div. 2011, 15, 721-731.

23. Hosseini, Y.; Rastgar, S.; Heren, Z.; Büyükgüngör, O.; Noroozi Pesyan, N. J. Chin. Chem. Soc. 2011, 58, 309-318.

24. Noroozi Pesyan, N.; Shokr, A. R.; Behroozi, M.; ^ahin, E. J. of the Iranian Chem. Soc. 2013, 10, 565-575.
25. Noroozi Pesyan, N.; Garib, A.; Behroozi, M.; Shokr, A. Arab. J. Chem. 2013, in press.

26. Noroozi Pesyan, N.; Kimia, M. A.; Jalilzadeh, M.; ^ahin, E. A. J. Chin. Chem. Soc. 2013, 60, 35-44.

27. Brown, DJ.; Mason, SF. Chemistry of Heterocyclic Compounds. Vol. 16, John Wiley \& Sons Inc. New York, (1962)

28. McCallum, PBW.; Grimmett, MR; Blackman, AG.; Weavers, RT. Aust. J. Chem. 1999, 52,159-166.

29. Schriner RL, Fusan RC, Curtin DY, Morrill TC The systematic identification of organic compounds, 6th, Edn, John Wiley \& Sons, New York, (1980).

30. Witherell, R. D. The Stereoselective Synthesis of 13C2-labelled Lysines. M. Sc. Thesis, Dalhousie University, Halifax, Nova Scotia, Canada, (1999). 